\title{
Saluran Komunikasi Lembaga Riset Publik Dalam Penyiapan Teknologi Peternakan Mendukung Pengembangan Subsistem Agribisnis Hulu
}

\section{Communication Channel Of Public Research Institutes In The Creation Of Livestock Technology Supporting The Development Of Upstream Agribusiness Subsystem}

\author{
Vyta W. Hanifah ${ }^{1}$, Istriningsih ${ }^{2}$, dan Yovita Anggita Dewi ${ }^{1}$ \\ ${ }^{1}$ Balai Besar Pengkajian dan Pengembangan Teknologi Pertanian \\ Badan Penelitian dan Pengembangan Pertanian, Kementerian Pertanian \\ Jalan Tentara Pelajar No. 10 Bogor - Jawa Barat \\ ${ }^{2}$ Balai Pengelola Alih Teknologi Pertanian \\ Badan Penelitian dan Pengembanan Pertanian, Kementerian Pertanian \\ Jalan Salak No. 22 Bogor - Jawa Barat \\ Email:invy13@hotmail.com \\ Email:yovi_anggita@yahoo.com \\ Email : nieng_fun@yahoo.com
}

\begin{abstract}
ABSTRAK
Kajian ini bertujuan untuk merumuskan saluran komunikasi melalui penelusuran saluran komunikasi dalam penyiapan teknologi pertanian berbasis pengguna mendukung pengembangan subsistem agribisnis hulu. Kajian dilakukan bulan April-Agustus 2012 di lembaga Badan Penelitian dan Pengembangan Pertanian, swasta (PT Bina Mentari) dan perguruan tinggi (Fakultas Peternakan, IPB University). Hasil kajian menunjukkan bahwa proses penciptaan teknologi peternakan oleh lembaga riset publik belum mencerminkan adanya upaya penjaringan umpan balik dari pengguna, salah satunya sebagai akibat dari tidak berfungsinya komisi teknologi di daerah. Pembelajaran dari swasta dan perguruan tinggi mencerminkan adanya pola dan strategi komunikasi yang lebih baik, seperti berjalannya proses penjaringan isu dan informasi dari pengguna, umpan balik teknologi, serta after sales service.
\end{abstract}

Kata Kunci: saluran komunikasi, teknologi peternakan, subsistem agribisnis hulu, lembaga riset publik

\begin{abstract}
This study aimed to formulate the communication channel through tracking communication channels in the process of user-based agricultural technology creation to support the development of upstream agribusiness subsystem. The study was conducted in April-August 2012 at Indonesian Agency for Agricultural Research and Development, private sector (PT Bina Mentari) and university (Faculty of Animal Science of IPB University). The results indicated that the process of livestock technology development by public research institutes has not yet reflected the users feedback, due to the malfunctioning of the local technology commission. Lessons learned from private sector and university reflected the better pattern and communication strategies, such as user needs identification, feedback mechanism, and after sales service.
\end{abstract}

Keywords : communication channel, livestock technology, upstream subsystem agribusiness, public research institutes 


\section{PENDAHULUAN}

Konteks pembangunan ekonomi koridor Bali - Nusa Tenggara seperti yang tertuang dalam Master Plan Percepatan dan Perluasan Pembangunan Indonesia (MP3EI) menyebutkan bahwa wilayah Propinsi Nusa Tenggara Timur didominasi Iahan marginal berupa lahan kering. Menurut data Badan Pusat Statistik NTT (2012), luas lahan kering atau bukan lahan sawah di NTT mencapai $96 \%$ dari luas wilayah. Selain itu agroekosistem di NTT cukup beragam, dengan permasalahan yang relatif komplek baik ditinjau dari keadaan agroekologi (bentuk lahan, tanah dan iklim, vegetasi) dan kondisi sosial ekonomi masyarakat. Kondisi tersebut menyebabkan tantangan pembangunan di NTT khususnya pembangunan pertanian semakin meningkat.

Berbagai upaya perlu dilakukan khususnya untuk menjawab tantangan dan kebutuhan teknologi dalam optimalisasi potensi lahan marginal, salah satunya dengan dukungan penelitian dan pengembangan teknologi pertanian yang memadai. Dalam upaya tersebut, telah dikeluarkan Permentan Nomor 44 tahun 2011, tentang Pedoman Umum Perencanaan Penelitian dan Pengembangan Pertanian yang menjelaskan adanya empat tahapan dalam penyiapan dan penerapan teknologi pertanian, yaitu tahap penelitian, verifikasi, pengkajian, dan tahap diseminasi (Kementan 2011).

Pada tahap pengkajian teknologi, Balai Pengkajian Teknologi Pertanian (BPTP), yaitu Unit Pelaksana Teknis di Bawah Badan Penelitian dan Pengembangan Pertanian (Balitbangtan), memegang peranan penting untuk melalukan uji kesesuaian sosial, ekonomi, budaya, dan kelembagaan terhadap paket teknologi spesifik lokasi agar memperoleh model pengembangan dan paket teknologi (Kementan 2011). Keberadaan BPTP yang dibangun sejak tahun 1995 dimaksudkan sebagai jembatan penghubung antara kegiatan penelitian dan penyuluhan (Sarwani et al 2011). Kelembagaan BPTP dibangun di 33 provinsi di Indonesia, salah satunya di Provinsi Nusa Tenggara Timur (NTT). BPTP NTT telah banyak menghasilkan dan mengembangkan berbagai teknologi spesifik lokasi di lahan marginal.

Keberadaan BPTP NTT sebagai salah satu sumber teknologi turut mewarnai pengembangan komoditas pertanian dan peternakan, misalnya melalui model integrasi tanaman-ternak dan pemanfaatan limbah yang diwujudkan dalam pola jagung-sapi, kakaokambing, dan biogas. Komoditas jagung dan ternak di NTT tidak dapat terlepas dari kehidupan sehari-hari masyarakatnya. Oleh karena itu banyak dijumpai usahatani jagung maupun peternakan rakyat yang dikelola dengan sederhana. Sistem pertanian terpadu di lahan kering yang melibatkan tanaman semusim, tanaman tahunan, dan rumput pakan juga disebutkan oleh Iswandi (2010) sebagai salah satu strategi pengembangan lahan kering berlereng.

Permasalahan utama yang kerap dihadapi oleh lembaga publik penghasil teknologi adalah efektivitas dari proses transfer teknologi kepada pengguna (Bassi et al, 2014). BPTP NTT telah menghasilkan berbagai paket teknologi, namun pada beberapa kasus tingkat adopsinya masih relatif terbatas karena berbagai faktor. Hal ini bisa disebabkan karena ketidakseimbangan antara penciptaan teknologi dengan kebutuhan pengguna (Fujisaka, 1994), atau penerapan teknologi membutuhkan modal yang sangat tinggi (Fliert, 2010). Dengan demikian, supaya teknologi yang dihasilkan sesuai dengan kebutuhan pengguna (penyuluh dan petani) dan mendukung pengembangan agribisnis produk lokal, diperlukan suatu upaya proses penggalian kebutuhan teknologi dan strategi transfer teknologi yang tepat. Dalam prakteknya, perlu dibangun suatu pola komunikasi yang efektif dalam proses penciptaan dan transfer teknologi, sehingga menjadi efektif dan berdampak bagi pengguna. Sarwani et al (2011) juga menegaskan pentingnya peran communication and linkages dalam tahap identifikasi pengkajian yang dapat menjawab kebutuhan daerah karena adanya linkage dengan Pemerintah setempat.

Di sisi lain, disadari pula bahwa lembaga riset swasta sering melakukan langkah dan terobosan lebih baik dalam proses penyediaan teknologi khususnya pada tahap pemasalan/pemasarannya, sehingga teknologi hasil lembaga riset swasta sering lebih mudah dijumpai dan diadopsi pengguna. Lembaga riset swasta pun selalu menempatkan produknya dalam sistem agribisnis berkelanjutan bagi para konsumennya. Untuk itu, sangat menarik untuk mengkaji sistem inovasi yang selama ini dibangun dan diterapkan lembaga riset swasta. Keefektifitasan dan keberhasilan sistem inovasi pada lembaga riset swasta, diharapkan dapat menjadi pembelajaran bagi Balitbangtan, khususnya BPTP, dalam membangun sistem inovasi baik perakitan maupun penyalurannya, sehingga dapat memberi manfaat bagi pengembangan agribisnis produk lokal daerah.

Tujuan penulisan makalah ini adalah merumuskan saluran komunikasi melalui penelusuran saluran komunikasi dalam 
penyiapan teknologi pertanian berbasis pengguna mendukung pengembangan subsistem agribisnis hulu oleh BPTP NTT dalam kaitannya dengan Balai Penelitian Tanaman Serealia (Balit Serealia) sebagai instansi yang merilis teknologi jagung dan Loka Penelitian Sapi Potong (Lolit Sapi Potong) dengan teknologi ternaknya. Dari saluran tersebut, selanjutnya dirumuskan strategi komunikasi sebagai pembelajaran dari lembaga riset swasta dan perguruan tinggi. Dengan demikian diharapkan pembelajaran dari kajian ini dapat mendukung perumusan rekomendasi teknologi adaptif yang dapat menjawab kebutuhan pengguna dan mendukung pengembangan subsistem agribisnis hulu.

\section{METODE PENELITIAN}

Kajian ini melibatkan tiga instansi lingkup Balitbangtan yaitu BPTP NTT, Balit Serealia dan Lolit Sapi Potong sebagai lembaga riset publik yang memiliki mandat sebagai penghasil teknologi. Kajian ini juga melibatkan lembaga riset swasta yaitu perusahaan peternakan sapi potong dan lembaga riset dari perguruan tinggi. Lembaga riset swasta yang dikunjungi adalah PT Bina Mentari, yaitu sebuah perusahaan di bawah nama KIBIF yang bergerak dalam bidang usaha penyediaan sapi potong, baik berupa komoditas sapi (ternak hidup), daging, maupun produk olahannya melalui pengembangan produksi (pembibitan dan penggemukan), rumah potong hewan (RPH), dan pengolahan. Institusi perguruan tinggi yang dimaksud dalam kajian ini adalah Fakultas Peternakan, IPB University.

Pelaksanaan kegiatan di lapang pada bulan April - Agustus 2012. Pengumpulan data primer diperoleh melalui diskusi mendalam dengan pihak manajemen masing-masing instansi menggunakan panduan wawancara. Informasi mengenai saluran/proses komunikasi internal masing-masing instansi kemudian diterjemahkan dalam bentuk grafik/gambar alur, sehingga diperoleh gambaran singkat mengenai saluran komunikasi dalam proses perakitan teknologi jagung dan ternak sapi potong oleh BPTP NTT yang melibatkan teknologi hasil ciptaan Balit Serealia untuk teknologi jagung dan Lolit Sapi Potong untuk teknologi ternak sapi potong.

Data berasal dari lembaga riset swasta dan perguruan tinggi ditujukan pada faktorfaktor yang mempengaruhi efektivitas pola komunikasi dan keberhasilan lembaga tersebut dalam perakitan hingga penyaluran teknologi sebagai bahan pembelajaran bagi BPTP.
Pengumpulan data dalam hal ini dilakukan melalui comparative study dalam bentuk kunjungan langsung ke lokasi dan diskusi mendalam dengan manajemen tertinggi di lembaga tersebut.

Data sekunder diperoleh dari desk study terhadap laporan tahunan masingmasing instansi yang berisi laporan hasil capaian kegiatan selama tahun berjalan, yaitu tahun 2010 dan 2011. Selanjutnya gabungan informasi dari data primer dan sekunder dianalisis secara deskriptif kualitatif.

\section{HASIL DAN PEMBAHASAN \\ Kondisi Eksisting Saluran Komunikasi di Lembaga Riset Publik}

Saluran komunikasi yang

diidentifikasi dalam kajian ini dibedakan

menjadi dua tahap, yaitu tahap penentuan topik hingga perakitan teknologi dan tahap penyaluran teknologi hingga ke pengguna.

a) Saluran Komunikasi dalam Penentuan Topik hingga Perakitan Teknologi Mendukung Pengembangan Subsistem Agribisnis Hulu

Hasil kajian di tingkat lembaga riset publik menunjukkan keragaan yang serupa yaitu bahwa topik teknologi yang akan dirakit disesuaikan dengan Rencana Strategis (Renstra) Organisasi yang menginduk pada organisasi di atasnya.

Di tingkat BPTP NTT, terdapat perbedaan mekanisme penentuan topik antara sebelum tahun 2009 dan setelahnya. Hal ini disebabkan oleh non-aktifnya peran kelembagaan Komisi Teknologi sebagai sarana untuk menggali kebutuhan pengguna terhadap teknologi dan menyesuaikannya dengan potensi pengembangan wilayah dalam program-program pemerintah. Sebelum tahun 2009, Komisi Teknologi yang dibentuk sejak tahun 2002 banyak berperan dalam melakukan koordinasi pelaksanaan kegiatan penelitian/pengkajian dalam kaitannya dengan kebutuhan Pemda dan pengguna lainnya. Keterlibatan stakeholders yang meliputi semua unsur penentu kebijakan pembangunan pertanian di NTT, diantaranya Pemerintah Daerah, Balitbangda, dan Perguruan Tinggi, dalam tahapan penentuan topik pengkajian BPTP NTT masih besar. Namun setelah tahun 2009, keterlibatan tersebut menjadi sangat berkurang dan akibatnya topik penelitian/pengkajian yang disusun oleh BPTP NTT lebih banyak diselaraskan dengan program-program dari pemerintah pusat. Gambaran kondisi eksisting di atas ditampilkan pada Gambar dibawah ini. 


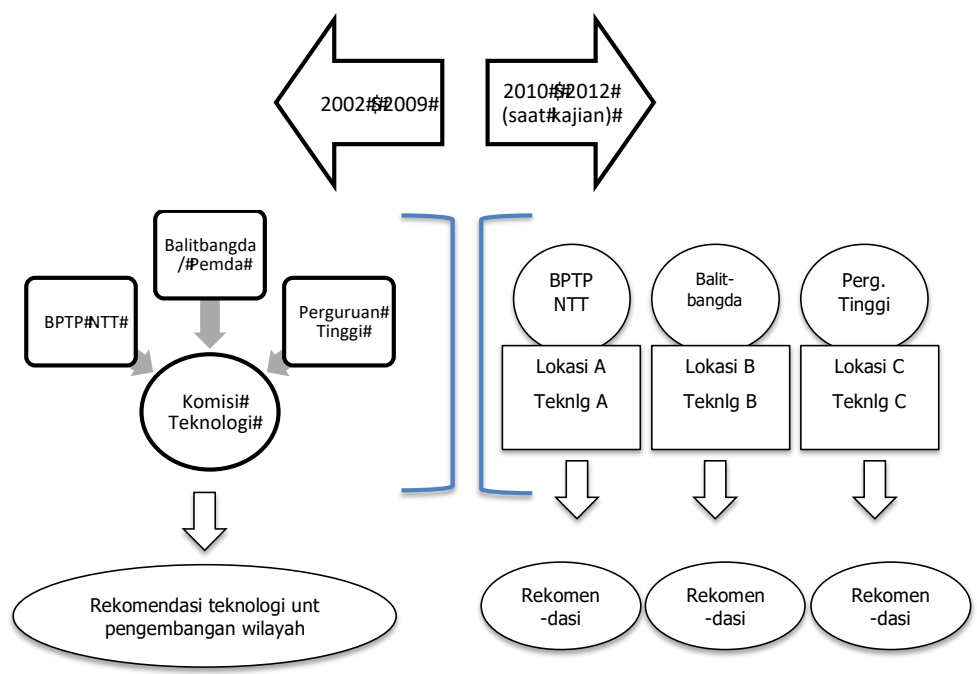

Gambar. Perbedaan saluran komunikasi dalam penentuan topik kegiatan penelitian/pengkajian sebelum dan sesudah tahun 2009 di BPTP NTT

Di Balit Serealia, proses penciptaan teknologi yang menghasilkan output berupa Varietas Unggul Baru (VUB) dilakukan oleh pemulia dengan penelitian on-station. Oleh karena itu, saluran komunikasi yang terjadi lebih banyak berada dalam lingkungan internal balai tersebut. Kegiatan pemuliaan merupakan kegiatan berantai tanpa menghentikan siklus pembentukan varietas meskipun VUB telah dilepas. Tabel dibawah ini menunjukkan peningkatan jumlah koleksi dari biodiversiti sereal yang dihasilkan oleh Balit Serealia

Tabel . Peningkatan koleksi plasma nutfah serealia Balit Serealia tahun 2009 dan tahun 2010

\begin{tabular}{lccc}
\hline \multicolumn{1}{c}{ Biodiversiti sereal } & \multicolumn{2}{c}{ Total koleksi (aksesi) } & $\begin{array}{c}\text { Peningkatan jumlah } \\
\text { koleksi }(\%)\end{array}$ \\
\cline { 2 - 3 } & 2009 & 2010 & 22 \\
Jagung & 515 & 626 & 130 \\
Sorgum & 83 & 191 & 180 \\
Gandum & 36 & 101 & 0 \\
Hermada & 2 & 2 & 83 \\
Millet/jewawut & 58 & 106 & 60 \\
Jali (Coix lacymajobi) & 5 & 8 & \\
\hline
\end{tabular}

Sumber: Highlight Balai Penelitian Tanaman Serealia $(2009,2010)$ - diolah

Saluran komunikasi dalam penentuan topik penelitian di Balit Serealia berawal dari pertemuan koordinasi internal dengan pembahasan yang mengacu pada Renstra Badan Litbang Pertanian dalam mewujudkan Empat Sukses Pembangunan Pertanian. Di lingkup internal, dalam proses tersebut tidak ada pelibatan stakeholders pengguna (BPTP, Komisi Teknologi, Balitbang Daerah, petani, swasta, dan lain-lain). Proses dan penajaman topik dilakukan secara internal pada saat Raker Lingkup Pusat Penelitian dan PengembanganTanaman Pangan (Puslitbang TP) yang juga dimanfaatkan sebagai sarana padu padan antar instansi lingkup Puslitbang
TP tersebut. Gambaran singkat mengenai proses ini ditampilkan pada Gambar 2.

Balit Serealia memiliki media untuk menampung umpan balik dari pengguna, salah satunya melalui website. Leeuwis (2004) menyatakan bahwa internet sebagai hybrid media memiliki beberapa aplikasi yang mendukung terciptanya intervensi komunikasi, diantaranya search and access, memory and feedback, advisory, self-help and request, dan public debate. Mekanisme perolehan umpan balik oleh Balit Serealia sejalan dengan salah satu aplikasi yang disebutkan di atas (memory and feedback). 


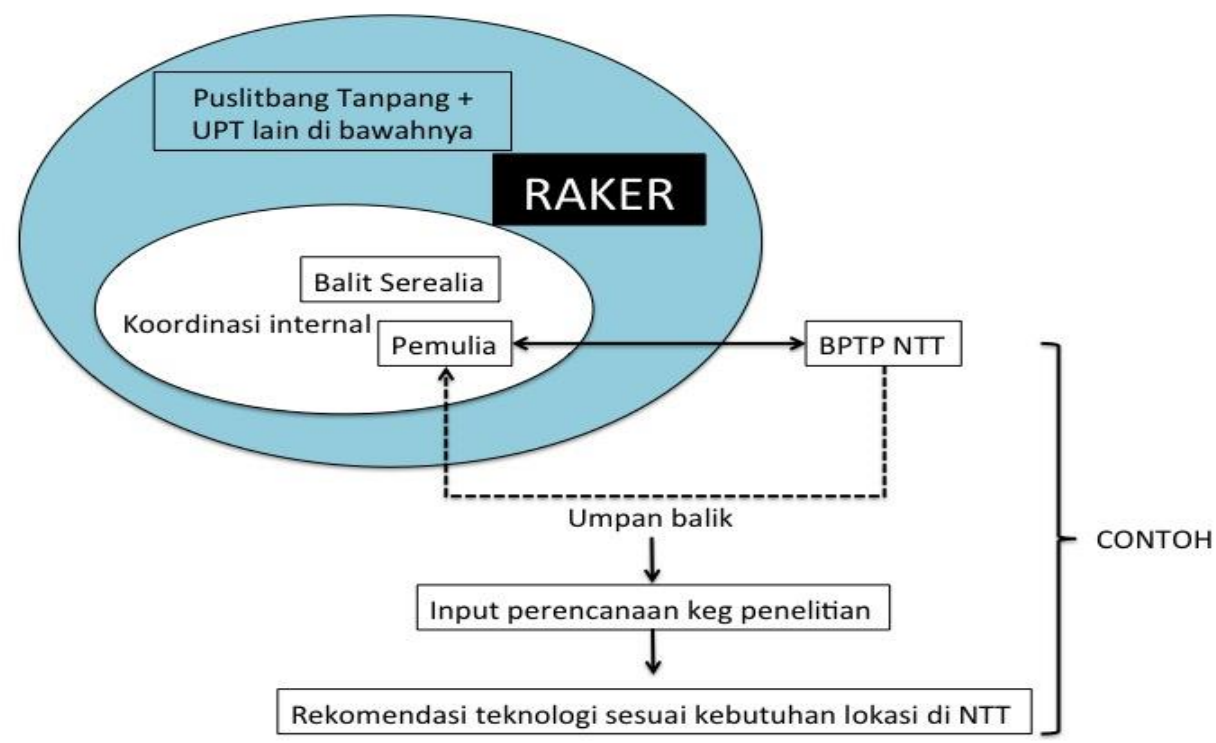

Gambar. Saluran komunikasi dalam penentuan topik perencanaan kegiatan penelitian di Balai Penelitian Tanaman Serealia

Umpan balik tersebut bukan merupakan input utama dalam penentuan topik penelitian, karena website lebih ditujukan untuk menampung keluhan/pertanyaan seputar pelayanan Balit Serealia kepada pengguna. Proses komunikasi terkait dengan upaya mendapatkan umpan balik dari pengguna sebagai input untuk topik penelitian dilakukan sendiri oleh pemulia Balit Serealia pada saat kunjungan pendampingan teknologi, misalnya Sekolah Lapang Pengelolaan Tanaman Terpadu (SL PTT) jagung. Seperti diilustrasikan dalam Gambar 2, tidak terlihat adanya alur komunikasi dua arah antara Balitsereal dengan BPTP NTT dalam perencanaan pengembangan teknologi jagung dalam SL PTT jagung. Umpan balik diperoleh dari aksi proaktif pemulia/peneliti Balit Serealia yang berkunjung ke BPTP NTT.

Hal lain yang dijadikan dasar pertimbangan bagi perencanaan kegiatan penelitian di Balit Serealia adalah terkait dengan fluktuasi kuantitas permintaan benih. Selain itu, pengalaman dalam kerjasama dengan swasta juga menjadi dasar pertimbangan untuk menentukan perencanaan penelitian. Kerjasama antara lembaga riset publik dan swasta sangat disarankan oleh Hayami dan Peterson (1972) terutama pada kegiatan penelitian yang memerlukan investasi besar seperti penelitian jagung hibrida.

Saluran komunikasi oleh Lolit Sapi Potong dalam proses penciptaan teknologi peternakan yang diterapkan di NTT ditunjukkan melalui kegiatan konsorsium peternakan di lahan kering yang dimulai sejak tahun 2010 dan berakhir pada tahun 2014. Kegiatan ini terfokus pada introduksi teknologi dalam sistem integrasi ternak sapi potong dan tanaman jagung. Alur komunikasi terlihat di antara stakeholders yang terlibat seperti ditunjukkan pada Gambar 3. Keterlibatan dalam kegiatan konsorsium memungkinkan Lolit Sapi Potong untuk berinteraksi dengan lebih banyak pengguna yang berarti meningkatkan arus komunikasi teknologi peternakan termasuk dengan institusi di luar Balitbangtan (swasta, KTNA, pemda, dan petani/peternak).

Dalam perkembangannya, kegiatan konsorsium kemudian memasukkan kegiatan super-imposed di Kebun Percobaan Naibonat dan di Desa Oebola, Kupang, yang juga ditujukan untuk mendukung unsur penelitian sebagai lembaga Litbang. Penelitian konsorsium ini dirasakan mempunyai kelebihan dibandingkan penelitian yang biasa dilakukan Lolit Sapi Potong, karena untuk menentukan teknologi introduksi terlebih dahulu melalui proses penggalian kebutuhan (need assessment) di lapangan yaitu melalui Participatory Rural Appraisal (PRA) untuk memotret kondisi eksisting peternakan di NTT. Teknik PRA untuk memecahkan permasalahan bidang pertanian bersama petani disarankan oleh beberapa studi sebelumnya seperti Cleaver (2001), Horne dan Stur (2003); dan Quarry dan Ramirez (2009). Studi tersebut menyebutkan bahwa teknik PRA memulai pemecahan permasalahan dengan pendekatan partisipatif melalui diskusi langsung dengan petani dan pengambilan keputusan secara aktif oleh petani. 


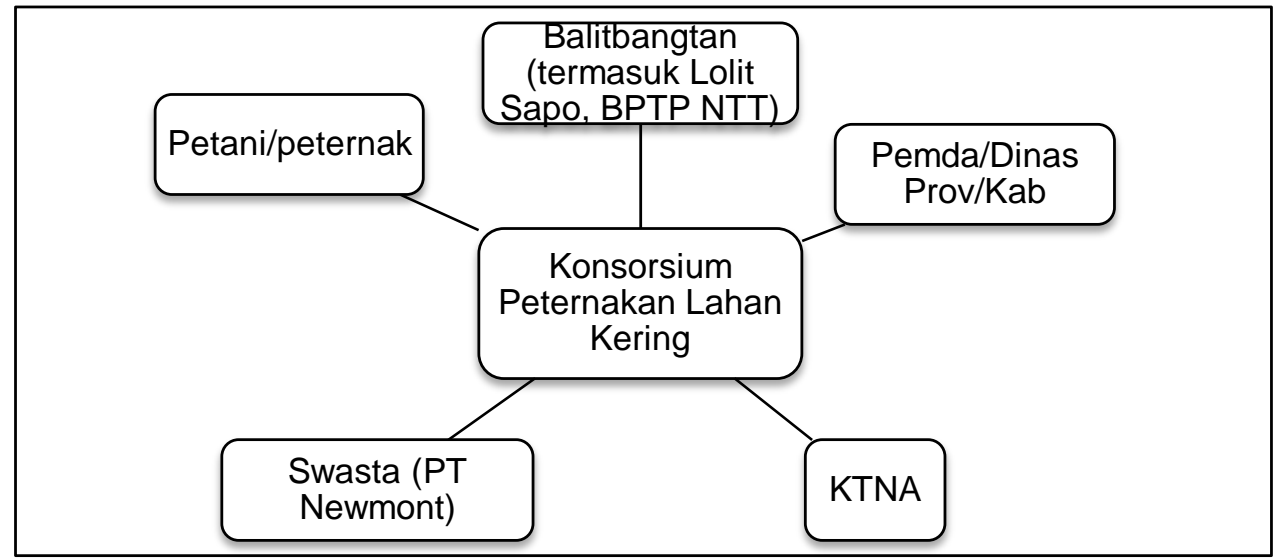

Gambar . Saluran komunikasi yang terjalin dalam kegiatan konsorsium peternakan di lahan kering NTT (2010-2014)

Teknologi introduksi diharapkan benarbenar sesuai dengan kebutuhan dan dapat mengatasi permasalahan pengguna. Dalam konsorsium tersebut, Lolit Sapi Potong juga memperoleh umpan balik dari BPTP NTT berupa data progress fisik maupun rekording dengan parameter yang diukur berupa data biologis. Gambaran kegiatan konsorsium peternakan di tingkat lapang ditampilkan pada Gambar di bawah ini.

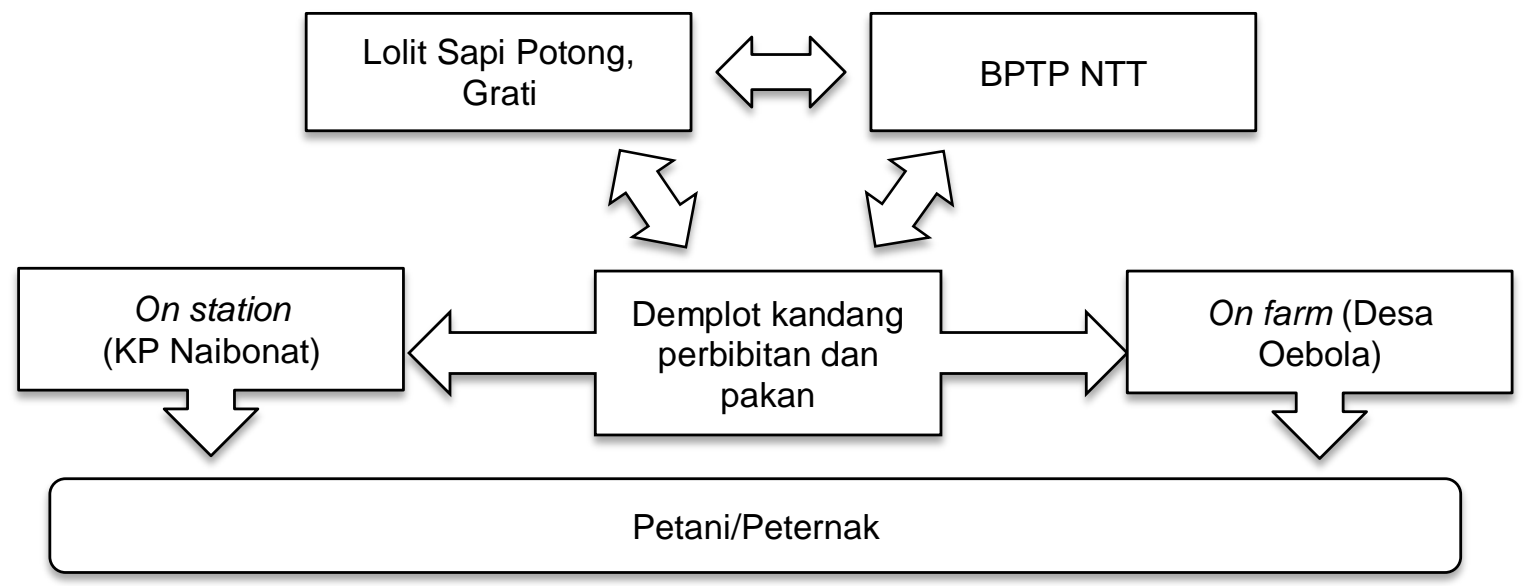

Gambar . Alur operasional yang dilakukan pada kegiatan konsorsium peternakan di lahan kering NTT

\section{b) Saluran Komunikasi dalam Penyaluran Teknologi Mendukung Pengembangan Subsistem Agribisnis Hulu}

BPTP NTT sudah banyak menghasilkan teknologi spesifik lokasi, namun demikian tingkat adopsi teknologi oleh pengguna cenderung lambat. Oleh karena itu, diperlukan upaya menggali informasi dan mengidentifikasi terkait dengan tantangan dan "sumbatan" komunikasi yang dihadapi dalam proses penyaluran teknologi dari BPTP ke pengguna. Horne dan Stur (2003) menegaskan perlunya keterampilan berkomunikasi ketika bekerjasama dengan petani sebagai mitra dalam mengembangkan berbagai teknologi di bidang pertanian.

Proses penyaluran komponen atau paket teknologi spesifik lokasi oleh BPTP NTT kepada pengguna dilakukan melalui berbagai metode, antara lain metode pelatihan, demplot, temu lapang, dan seminar. Media yang digunakan adalah media cetak (leaflet, buku success story, dII) dan elektronik (VCD). Stakeholders yang terlibat dalam proses penyaluran teknologi adalah penyuluh lapang (PPL), pemerintah daerah, pengurus kelompok tani, petani, aparatur desa, tokoh adat dan formulator swasta. Keterlibatan dan peran stakeholders tersebut diuraikan pada Tabel dibawah ini. Peran PPL secara khusus selain seperti tercantum dalam Tabel dibawah ini, juga diharapkan mengarah pada pemberdayaan petani melalui tiga peran sebagai dinamisator, fasilitator dan motivator (Indraningsih et al, 2010). 
Tabel . Keterlibatan dan pembagian peran berdasarkan stakeholders analysis pada saluran komunikasi dalam penyaluran teknologi kepada pengguna

\begin{tabular}{ll}
\hline \multicolumn{1}{c}{ Stakeholders } & \multicolumn{1}{c}{ Peran } \\
\hline Petani & Menerima dan menerapkan teknologi \\
Pengurus Kelompok Tani & Menentukan calon petani kooperator \\
& Menyampaikan teknologi ke petani yang lain \\
PPL & Memfasilitasi proses penyaluran teknologi \\
& Menyampaikan informasi teknologi \\
Pemerintah Daerah & Menentukan lokasi kegiatan \\
& Memfasilitasi proses penyaluran teknologi \\
Aparatur desa dan tokoh adat & Scalling up \\
& Memfasilitasi proses penyaluran teknologi \\
Formulator swasta & Menyampaikan teknologi ke petani yang lain \\
& Membantu menyediakan input \\
& Menyampaikan informasi teknologi \\
\hline
\end{tabular}

Penyaluran teknologi yang diintroduksikan kepada petani dalam bentuk paket, sehingga terbuka kemungkinan beberapa komponen teknologi yang mungkin tidak spesifik lokasi. Hanya ada beberapa komponen teknologi saja yang mampu diadopsi oleh petani karena alasan kemudahan untuk diterapkan, salah satunya adalah komponen teknologi varietas. Akibat dari introduksi dalam bentuk paket teknologi adalah profitabilitas usahatani menurun yang disebabkan relatif tingginya input yang dibutuhkan (petani miskin dan tidak mampu), selain itu kelembagaan di petani belum cukup kuat. Menurut Saragih (2010) kelembagaan petani merupakan kunci penting bagi pembangunan pertanian dengan pendekatan agribisnis yang perannya diwujudkan melalui kegiatan selain usahatani (non-usahatani).

Saluran komunikasi yang terjalin pada proses penyaluran teknologi/informasi hasil penelitian di Lolit Sapi Potong berada dalam ranah diseminasi baik melalui komunikasi searah maupun dua arah. Kegiatan diseminasi dikelompokkan ke dalam 4 kegiatan, yaitu: (1) peragaan teknologi dan informasi (gelar teknologi untuk jagung, ekspose, visitor plot, dan show-room), (2) komunikasi tatap muka (temu lapang dan seminar), (3) pengembangan informasi, dan (4) penyebarluasan varietas unggul jagung Balit Serealia di tingkat petani. Selain itu, juga terdapat pelayanan pelatihan bagi peneliti BPTP untuk mendalami ilmu tentang serealia. Proses ini ditempuh melalui saluran komunikasi formal (proses surat menyurat dari pimpinan masing-masing lembaga).

Mengacu pada tupoksi yang melekat, alokasi kegiatan penyaluran teknologi (diseminasi) di Lolit Sapi Potong memang relatif tidak besar (secara anggaran hanya $2 \%$ dari total anggaran). Pada dasarnya, teknologi yang dihasilkan Lolit Sapi Potong adalah teknologi dasar yang kadangkala masih memerlukan penelitian adaptasi di suatu lokasi tertentu oleh
BPTP. Bentuk kegiatan diseminasi yang dilakukan Lolit Sapi Potong, antara lain: mengikuti pameran secara aktif, pencetakan juknis, pembuatan panel pameran/poster, menjadi narasumber, dan beberapa tahun yang lalu sempat aktif dalam forum dialog interaktif di siaran radio. Monitoring untuk mendapatkan umpan balik dilakukan melalui kuesioner/angket yang disebarkan pada saat pameran/kunjungan, namun hal ini bersifat insidentil. Tidak saja dari peternak, respon umpan balik yang diperoleh melalui angket juga berasal dari para pengusaha di bidang peternakan yang hadir pada pameran.

Terkait dengan upaya pengembangan subsistem agribisnis hulu, saluran komunikasi dalam penyaluran teknologi ini merupakan simpul pertama dihasilkannya inovasi yang dapat menjawab kebutuhan penggunanya. Selanjutnya, inovasi tersebut merupakan simpul kedua dihasilkannya produk berbasis kebutuhan pengguna. Terakhir, produk berbasis pengguna merupakan input penting dan utama dalam pengembangan subsistem agribisnis hulu mendukung pemberdayaan sumberdaya lokal daerah (Saragih, 1998). Dengan demikian, peran inovasi sejak direncanakan hingga proses perakitannya dan penyalurannya memegang peranan penting dalam menghasilkan produk berbasis pengguna berdasarkan strategi pengembangan subsistem agribisnis hulu. Hal tersebut selaras dengan yang dikemukakan oleh Ashby dan Sperling (1995), yang menyebutkan bahwa kegiatan penelitian dan pengembangan pertanian yang melibatkan pengguna (clientdriven) merupakan prinsip sukses sebuah inovasi.

\section{Pembelajaran dari Lembaga Riset Swasta dan Perguruan Tinggi}

Berdasarkan hasil diskusi dengan lembaga riset swasta dan perguruan tinggi, beberapa hal yang dapat dijadikan 
pembelajaran terhadap proses komunikasi dalam penciptaan dan penyaluran teknologi, antara lain: Pertama, orientasi dari sebuah teknologi yang diciptakan. Dari pengalaman PT Bina Mentari, proses penciptaan teknologi didasarkan pada kebutuhan pasar atau bertujuan komersial dan umumnya bersifat jangka pendek (kebutuhan saat ini). Dengan mengacu pada kebutuhan pasar dan tujuan komersial, maka hal utama yang harus dipenuhi adalah standarisasi produk agar sesuai dengan kebutuhan dan keinginan pengguna (konsumen). Perusahaan mengidentifikasi produk yang laku di pasaran, kemudian hasilnya digunakan sebagai bahan riset untuk menghasilkan produk sejenis, namun tetap mencirikan produk perusahaan dan harganya bersaing. Sedangkan dari pengalaman Fakultas Peternakan, IPB University, jenis teknologi yang akan diciptakan disesuaikan dengan kondisi pengguna yang sudah jelas sasaran masyarakatnya, karena berada dalam skema program pengabdian masyarakat, seperti Desa Binaan Mahasiswa, Kuliah Kerja Praktek, Mobil Nutrisi dan Produksi Ternak Keliling, dan program kerjasama dengan Sarjana Membangun Desa khususnya yang menangani ternak.

Kedua, jaminan mutu menjadi perhatian utama bagi lembaga riset swasta dan salah satu aspek penentu dalam proses pemasaran produknya. Dampaknya adalah tingkat ketertarikan pengguna terhadap produk swasta sangat tinggi, bahkan promosi produk tersebut mampu mempengaruhi persepsi masyarakat dan penyuluh. Dengan demikian, pembelajaran mengenai aspek "jaminan mutu produk" dari pihak swasta menjadi penting untuk menjadi bahan masukan bagi Balitbangtan dalam hal sistem transfer teknologi.

Ketiga, proses komunikasi mulai dari penciptaan sampai dengan penyaluran produk oleh PT Bina Mentari, pada dasarnya telah berpijak pada prinsip kesesuaian untuk pengguna (konsumen), sehingga diharapkan tidak ada produk yang tidak diterima konsumen. Selain itu, perusahaan juga menjaring umpan balik dari pengguna misalnya melakukan riset sederhana untuk melihat tingkat preferensi konsumen dengan media kuesioner. Prinsip ini pun diterapkan oleh Fakultas Peternakan, IPB University, ketika melakukan perluasan skala implementasi teknologi yang disebut dengan istilah "polarisasi" yaitu upaya mengatasi berbagai respon yang muncul akibat scalling-up implementasi teknologi. Dari pengalaman ini terlihat adanya kesiapan lembaga riset tersebut untuk menyiapkan skenario lain sehingga teknologi tetap diterima dan bermanfaat bagi pengguna.

\section{Rekomendasi Saluran Komunikasi dalam Strategi Pengembangan Subsistem Agribisnis Hulu}

Dalam studinya, Nainggolan dan Aritonang (2012) menyebutkan bahwa subsistem agribisnis hulu merupakan subsistem yang menghasilkan inovasi untuk mendapatkan produk akhir berkualitas. Mencermati strategi pengembangan subsistem agribisnis hulu, salah satu rekomendasi untuk meningkatan fungsi saluran komunikasi dalam penyiapan dan penyaluran inovasi adalah perlunya menghidupkan kembali komisi teknologi atau merumuskan bentuk kelembagaan pengganti komisi teknologi untuk membantu BPTP dalam menentukan arah kebijakan dan diseminasi berbasis pengguna. Kelembagaan menurut Soekartawi (2001) sangat penting, baik formal maupun nonformal.

Sejak kajian ini dilakukan tahun 2012 hingga saat ini (tahun 2019), BPTP lebih banyak dihadapkan pada tugas-tugas untuk menyukseskan kegiatan-kegiatan dari pusat/nasional (pendekatan top down). Pendekatan ini menjadikan perakitan teknologi di BPTP kurang mengedepankan alur komunikasi BPTP dengan pengguna di daerah (pendekatan bottom-up relatif terabaikan). Sehingga teknologi yang dihasilkan BPTP tidak sepenuhnya mencerminkan dan menjawab kebutuhan teknologi di daerah. Pembelajaran dari lembaga riset swasta juga menunjukkan bahwa lembaga riset swasta memiliki kekuatan lebih baik dalam hal komunikasi dua arah, yaitu komunikasi dari penghasil teknologi (lembaga riset swasta) ke pengguna (konsumen produk lembaga) dan dari pengguna ke lembaga. Proses ini sepenuhnya dapat diadaptasikan dan diintegrasikan dalam kegiatan BPTP. Dengan demikian, melalui kajian ini rekomendasi yang perlu dirumuskan adalah penguatan proses umpan balik untuk mendapatkan input yang berguna bagi proses menghasilkan inovasi.

Dalam subsistem agribisnis hulu (upstream agribusiness), para pelakunya, yang dalam kasus ini adalah BPTP, harus menjalin koordinasi dan komunikasi dengan pelaku subsistem usahatani (on farm agribusiness), subsistem agribisnis hilir (downstream agribusiness), dan subsistem jasa penunjang (supporting system agribusiness). Keterlibatan multi stakeholders sejak awal proses ini sangat penting guna menciptakan rasa memiliki terhadap keluaran (Akpo et al, 2014), yang dalam hal ini berupa pengembangan sistem agribisnis hulu. Untuk itu, diperlukan pembenahan proses perencanaan untuk menghasilkan inovasi secara kolaboratif, dimulai dengan konsep pembangunan pertanian di tingkat kabupaten yang dilakukan dengan pendekatan wilayah, berdasarkan 
agroekosistem atau cluster pengembangan komoditas. Peran BPTP adalah membantu identifikasi awal melalui kajian-kajian spesifik lokasi, kemudian mengembangkan model bersama stakeholders terkait, dan mendampingi pengembangan model dalam bentuk penyediaan informasi dan teknologi. Melalui pendekatan ini, maka kelompok sasaran/target kegiatan BPTP menjadi jelas.

Sementara itu, proses komunikasi dalam perakitan teknologi antara BPTP NTT dengan Lolit Sapi Potong dan Balit Serealia sudah cukup intensif dan tidak banyak ditemukan kendala komunikasi. Namun demikian, hasil kajian ini menemukan bahwa setelah teknologi disalurkan ke pengguna, tidak ada proses penyampaian umpan balik dari BPTP NTT kepada Lolit Sapi Potong maupun Balit Serealia. Oleh karena itu, rekomendasi strategi komunikasi diarahkan pada perencanaan kegiatan transfer teknologi dan umpan balik antar institusi dalam bentuk padupadan yang efektif dan efisien serta mampu mengakomodir kesenjangan yang muncul antara teknologi keluaran balai penelitian dengan respon pengguna teknologi yang ditemui BPTP saat berada di lapangan.

\section{KESIMPULAN}

- Saluran komunikasi pada lembaga riset publik dalam penyiapan teknologi peternakan berbasis pengguna mendukung pengembangan subsistem agribisnis hulu secara kelembagaan masih belum mencerminkan adanya upaya penjaringan umpan balik dari pengguna, sehingga pelibatan stakeholders belum terlihat jelas, meskipun dari hasil diskusi dapat dipetakan peran masing-masing stakeholders menggunakan pendekatan stakeholder analysis. Pada kenyataannya, peran tersebut belum berjalan sebagaimana mestinya, salah satu akibatnya dibuktikan oleh non-aktifnya Komisi Teknologi. Pada umumnya lembaga riset publik menggunakan acuan rencana strategis (renstra) untuk menentukan topik penelitian, terutama juga dengan adanya program top down, sehingga dimungkinkan bahwa topik tersebut belum atau tidak sesuai dengan kebutuhan pengguna.

- Saluran komunikasi yang terjalin dalam proses penyaluran teknologi jagung dari Balit Serealia ke BPTP NTT ditunjukkan oleh kegiatan uji-multilokasi varietas jagung di NTT yang melibatkan komunikasi personal antara peneliti di kedua instansi. Sedangkan saluran komunikasi yang terjalin antara Lolit Sapi
Potong dan BPTP NTT ditunjukkan melalui kegiatan konsorsium peternakan di lahan kering. Proses komunikasi dalam penyaluran teknologi di antara lembaga riset publik terlihat lebih terorganisir dengan baik, terlepas dari apakah teknologi itu yang benar-benar dapat menjawab kebutuhan pengguna.

- Lembaga riset non publik (swasta) mengedepankan dan menempatkan pengguna sebagai mitra yang sangat berperan dalam menghasilkan produkproduk (teknologi) yang berkualitas. Pendekatan ini menyebabkan terjalinnya arus komunikasi yang sangat baik dari dua belah pihak. Adanya jaminan mutu produk (after sales service) oleh lembaga riset swasta, dapat dijadikan contoh bagi Balitbangtan, khususnya Balai Penelitian dan BPTP, sebagai upaya meningkatkan kualitas teknologi dan eksistensi lembaga.

Saran:

Rekomendasi strategi komunikasi yang dikemukakan dari hasil kajian ini perlu ditinjau lebih lanjut. Disarankan untuk dilakukan suatu pertemuan konsolidasi yang melibatkan pelaku subsistem agribisnis di hulu, di hilir, pelaku subsistem usahatani dan pelaku subsistem jasa penunjang untuk saling memberikan umpan balik pengembangan sistem agribisnis itu sendiri.

\section{UCAPAN TERIMA KASIH}

Penulis menyampaikan ucapan terima kasih kepada Prof. Dr. Ir. Erizal Jamal yang telah memberikan saran masukan dalam Workshop Penyusunan Strategi Komunikasi sebagai bagian dari tahapan kegiatan yang dilakukan dalam riset berjudul Kajian Model Pengembangan Strategi Komunikasi dalam Proses Penciptaan Inovasi Teknologi Spesifik Lokasi Mendukung MP3El (Studi Kasus di Lahan Marjinal Lokasi Pertanian Tanaman Pangan dan Peternakan), yang didanai oleh Insentif Peningkatan Kemampuan Peneliti dan Perekayasa, Tahun 2012.

\section{DAFTAR PUSTAKA}

Akpo, E. Crane, T.A., Vissoh, P.V. dan Tossou, R.C. 2014. Co-production of Knowledge in Multi-stakeholder Processes: Analyzing Joint Experimentation as Social Learning. The Journal of Agricultural Education and Extension, vol. 21 no. 4, pp. 369-388.

Ashby, JA dan Sperling, L $1995 .$. 'Institutionalizing Participatory, ClientDriven Research and Technology 
Development in Agriculture'. Development and Change, vol. 26, hal: 753-770.

Badan Pusat Statistik. 2012. Nusa Tenggara Timur dalam Angka 2012, BPS NTT, Kupang.

Bassi, N. S. S., Silva, C. L., Schneider, A. H., dan Carvalho, H. G. 2014. Controversies about the process of technology transfer from public research institutions in Brazil: The case of the Brazilian agricultural research corporation - Embrapa. Journal Technology Management of Innovation, vol. 9 no. 3, pp. 182-195.

Cleaver, F. 2001. Institutions, Agency and the Limitations of Participatory Approaches to Development, in Cooke $B$ and Kothari $U$ (eds.), Participation: The New Tyranny?, Zed Books, London, New York, hal. 36 55.

Fliert, E. Jamal. E. dan Christiana, B. 2010. The Do-It-Yourself formula - Internalising participatory communication principles to support rural development in Eastern Indonesia. Prosiding 9th European IFSA Symposium, 4-7 July 2010, Vienna (Austria). pp. 585-593.

Fujisaka, S. 1994. Learning from six reasons why the farmers not adopt innovations intended to improve sustainability of upland agriculture. Agricultural Systems, 46, pp. 409-425.

Hayami, Y \& Peterson, W. 1972. 'Social Returns to Public Information Services: Statistical Reporting of U.S. Farm Commodities', American Economic Review, vol. 62 no. 1, pp. 119 - 130 .

Horne, PM \& Stur, WW. 2003. Pemecahan masalah bidang pertanian bersama petani kecil - cara memulai pendekatan partisipatif, trans. M Tuhulele, TM Ibrahim, Ibrahim, DAH Suparto, Heriyanto, Elvira dan Tugiman, Monograph ACIAR No. 99b, ACIAR \& CIAT, buku asli diterbitkan pada tahun 2003.

Hotden, LNHL dan Aritonang, J. 2012. Pengembangan sistem agribisnis dalam rangka pembangunan pertanian berkelanjutan. Prosiding Seminar Nasional Pertanian Presisi Menuju Pertanian Berkelanjutan. Medan 3 April 2012. BKS-PTN Wilayah Barat Bidang Ilmu-IImu Pertanian.

Indraningsih, KS, Sugihen, BG, Tjitropranoto, P, Asngari, PS, dan Wijayanto, H. 2010. 'Kinerja penyuluh dari perspektif petani dan eksistensi penyuluh swadaya sebagai pendamping penyuluh pertanian', Analisis Kebijakan Pertanian, vol. 8 no. 4, pp. 303-321.

Iswandi. 2010. Inovasi teknologi konservasi lahan kering berlereng dan strategi pengembangannya, Badan Penelitian dan Pengembangan Pertanian, Jakarta Selatan.

Kementerian Pertanian. 2011. Permentan No. 44 Tahun 2011, Kementan, Jakarta.

Leeuwis, C. 2004. Communication for rural innovation: rethinking agricultural extension, with Ban, AW van den, Blackwell Publishing, Oxford, original work published 1974.

Quarry, W and Ramirez, R. 2009. Communication for Another Development: Listening Before Telling, Zed Books, London, New York.

Saragih, B. 1998. Kumpulan Pemikiran Agribisnis: Paradigma Baru Pembangunan Ekonomi Berbasis Pertanian. Yayasan Persada Mulia Indonesia.

Saragih, B. 2010. Agribisnis paradigm baru pembangunan ekonomi berbasis pertanian, IPB Press dan Food and Agribusiness Center, Bogor.

Sarwani, M, Jamal, E, Subagyono, K, Sirnawati, E, dan Hanifah, VW. 2011. 'Diseminasi di BPTP: pemikiran inovatif transfer teknologi spesifik lokasi', Analisis Kebijakan Pertanian, vol. 9 no. 1, pp. 7389.

Soekartawi. 2001. Agribisnis Teori dan Aplikasinya. PT Raja Grafindo. Jakarta. 